Сања Гавриловић

Архив Војводине

Нови Сад

sanja.g@arhivvojvodine.org.rs
Оригиналан научни рад

примљено: 14. април 2014

прихваћено: 1. октобар 2014

\title{
ЈЕДНО ПИСМО ИЗ БАЈЕ 1850. ГОДИНЕ
}

Сажетак: Баја је 1850. била један од центара Војводства Србије и Тамишког Баната. У њој је српски народ још увек представљао изразиту већину. У писму, које је тема овог рада, као једну од најважнијих вести Србин из Баје, студент медицине у Пешти, Павле Ивановић, наводи нереде које су изазвали мађарски становници Баје и околине, дошавши у град да се жале управитељу Војводства генералу Фердинанду Мајерхоферу, који се нашао у Баји обилазећи места Круновине марта 1850. године. Са Мајерхофером се у Баји нашао и поджупан Исидор Николић, који је заједно са генералом заузео веома негативан став према мађарским молбама и жељама уз речи да се они налазе у Баји, која је део Војводства Србије и Тамишког Баната, те да су у њој заступљени, пре свега, српски интереси.

Кључне речи: Баја, Војводство Србија и Тамишки Банат, Павле Ивановић, Васа Арновљевић, Фердинанд Мајерхофер, Исидор Николић.

Као један од важнијих центара Бачке жупаније Баја се помиње веома рано, још од периода угарске средњовековне државе. С обзиром на то да су Срби тада само делимично насељавали територију горње Бачке, односно средње Мађарске, нема поузданих података о српском присуству у Баји у то време. После коначног турског освајања Бачке 1541. и стварања Будимског пашалука, Баја је као и многа места у Угарској остала готово пуста, да би неколико година касније на тим територијама били насељени српско и друго словенско становништво. ${ }^{1}$ После ослобођења јужноугарских области, а тиме и Бачке, у Великом бечком рату, за време почетне управе Хабзбурга, Срби и Буњевци се помињу готово као једино становништво Баје. ${ }^{2}$ Од друге половине XVIII века у Бају се досељавају Мађари, као чиновници и официри, и Немци као занатлије, па од тада почиње опадање српске већине у граду. Током XIX века број српских домова је опао скоро за трећину у односу на ранији период. ${ }^{3}$ Почетком XX века Срби у Баји су представљали минорну,

\footnotetext{
${ }^{1}$ Динко Давидов, Споменици будимске епархије, Нови Сад 1990, 284.

${ }^{2}$ Као већ признати лекар, Ивановић је 1862 . написао кратак спис о прошлости Баје и њеној, првобитној, српској већини (Павле Ивановић, Нешто из прошлости вароши Баје, Летопис Матице српске, бр. 104, Пешта 1862, 131-132).

${ }^{3}$ У XVIII веку број српских житеља у Баји је износио њих 800-900, на број становника око 1.200, а у XIX
} 
занемарљиву мањину од једва 1\%. Према подацима из 1905. године број грађана Баје је износио 20.361 душу, од чега су само 203 лица српске националности. ${ }^{4}$

Управо у тој, још увек у XIX веку, доста јакој српској средини, настало је писмо чија је садржина предмет разматрања у овом раду. Написао га је 1850. године тада студент медицине, каснији лекар, Павле Ивановић, свом школском другу у Пешту, Васи Арновљевићу ${ }^{5}$, каснијем секретару Великокикиндског диштрикта. ${ }^{6}$

Баја је 1850. била једно од значајнијих места Војводства Србије и Тамишког Баната, које је прокламовано као посебна Круновина у Монархији у периоду 1849-1860. године. Она је за српски народ у Монархији била више казна него награда за њихову изражену борбу у Револуцији 1848/1849, на царској страни, а далеко од Српске Војводине створене на Мајској скупштини 1848. године. ${ }^{7}$

У састав Српске Војводине ${ }^{8}$ 1848/1849. улазили су Срем, Барања, Бачка, Банат са целокупним војним областима (границама) и Великокикиндским и Потиским диштриктом, док је у састав Војводства Србије и Тамишког Баната ушла Бачка, али без области Шајкашког батаљона, и цео Банат, али без Војне границе. Од Срема су ушли у састав само Илочки и Румски срез, док је Сремска војна граница, укључујући и Карловце, остала изван Војводства. Овако крње Војводство није било више српско ни по територијама а ни по етничком саставу. ${ }^{9}$

У таквом Војводству службени језик је био немачки, чиме су били незадовољни други народи, поготово Мађари, који су се осећали изопштено и

веку по пописима српских житеља 300-400 на укупан број становника од преко 2.500 (Д. Давидов, Нав. дело, 264).

${ }^{4}$ Од укупног броја становништва (мушког и женског) Баје у износу 20.361, највише је било Мађара 16.308, зарим Буњеваца 2.221, Немаца 1.571, Срба 203, Словака 40, Хрвата 18 (Мато Косовац, Српска православна митрополија карловачка, Загреб 2012 (репринт), 445).

${ }^{5}$ Василије Арновљевић је рођен у Темишвару око 1830, а умро у Великој Кикинди 1877. године. Студирао је у Пешти као питомац фонда Саве Текелије од 1846. до 1851. Прво је завршио филозофију а потом и права. Као студент филозофије 1847. године био је активни учесник и члан српских омладинаца у Пешти, међу које је тада стигао и Светозар Милетић. После завршених студија отишао у Кикинду, где је имао адвокатску канцеларију. Захваљујући своме угледу, али и очигледној помоћи свог школског друга, угледног лекара из Баје Павла Ивановића, биран је 1860. за сенатора Великокикиндског диштрикта. Његовом смрћу 1877. Срби у Банату, посебно у Диштрикту, изгубили су великог и преданог борца за слободу и равноправност српског народа у Угарској (Милица Бујас, Арновљевић, Василије, Српски биографски речник, књ. 1 (А-Б), Нови Сад 2004, 265).

${ }^{6}$ Архив Војводине, фонд (ф) 444, Збирка доктора Јована Милекића, 1841-1963, а. ј. 190.

${ }^{7}$ Славко Гавриловић, О борби Срба у Хабзбурикој монархији за политичко-територијалну аутономију 1690-1850, Зборник Матице српске за историју, св. 43, Нови Сад 1991, $22-23$.

${ }^{8}$ О уводним збивањима Револуције и почетка стварања српских националних програма и проглашењу Српске Војводине на Мајској скупштини вид.: Јаков Игњатовић, Рапсодије из прошлог српског живота, Нови Сад 1953, 70-79; Ђерђ Шпира, На прагу братоубилачког рата, Зборник радова Срби и Мађари у Револуичиј 1848-1849. године, Београд 1983, 3-57; Славко Гавриловић, Политичка борба за Српску Војводину у Аустријској иаревини 1848-1849, Зборник радова Српски покрет у Револуцији 1848-1849, Нови Сад 2000, 7-33; Љубомирка Кркљуш, Правна историја српског народа, Нови Сад 2002, 391-392; Дејан Микавица, Српска Војводина у Хабзбурикој монархији 1690-1920, Нови Сад 2005, 23-38; Дејан Микавица - Владан Гавриловић - Горан Васин, Знаменита документа за историју српског народа $1538-1918$, Нови Сад 2007, 241-244.

9 У Војводству је по попису 1850-1851. било 1.426.221 становник, од тога 397.459 Румуна, 335.080 Немаца, 321.110 Срба, 221.845 Мађара итд. (С. Гавриловић, О борби Срба у Хабзбурикој монархији..., 22; Д. Микавица, Српска Војводина..., 39). 
кажњено за своју „револуционарну борбу“. Нестали су у потпуности мађарски називи, који су замењени прво српским па потом немачким називима. Када је 1854. немачки језик постао званичан за сваки вид комуникације у Војводству, германизација је била потпуна, а незадовољство Мађара на врхунцу. ${ }^{10}$

У писму, које је тема овог рада, као једну од најважнијих вести Србин из Баје, студент медицине у Пешти, Павле Ивановић, ${ }^{11}$ наводи нереде које су изазвали мађарски становници Баје и околине, дошавши у град да се жале управитељу Војводства генералу Фердинанду Мајерхоферу ${ }^{12}$, који се нашао у Баји обилазећи места Круновине марта 1850. године. Са њим се у Баји нашао и поджупан Исидор Николић $^{13}$, који је заједно са Мајерхофером заузео веома негативан став према

\footnotetext{
${ }^{10}$ Ипак, и таква немачка управа је за Србе била знатно боља од некадашње мађарске, и многи Срби су добили учешће у администрацији и звања. Како наводи Михајло Полит-Десанчић: „Иако је та Војводина носила у званичном погледу немачки тип, ипак су натписи свуда гласили 'српска Војводина', а Мађар из Угарске путовао je у 'szerb Vajdasag' као у другу круновину са пасошем“ (Д. Микавица, Српска Војводина..., 42-44).

11 Павле Ивановић Сентивански је рођен у Баји 1831. године и умро је такође у Баји 1888. године. Био је нећак песника Јована Пачића. Завршио је основну школу у Баји а средњу и студије у Пешти. Уписао је 1849. године студије филозофије у Пешти, да би потом прешао на медицину, коју је завршио 1857. Као студент био је стипендиста фонда Саве Текелије. Као лекар вратио се у Бају и био признат као стручњак из области опште медицине. Бавио се и књижевношћу и 1852. још као млад студент написао једну родољубиву песму, која је објављена у часопису Седмица и због које је замало изгубио стипендију. Био је милетићевац и истакнути члан Српске народне слободоумне странке, на чијој је листи изабран за посланика на Народно-црквеном сабору исте године, као и на Сабору 1872. Као истакнути лекар и грађанин добио је племство и назив Сентивански, и био члан градског представништва у Баји. Од 1861. постао је редовни и истакнути члан Матице српске. Као угледни грађанин помагао је пре свих сиромашне ђаке и студенте и куповао им књиге. Имао је и сам запажену и богату библиотеку у којој су се налазиле књиге владике црногорског Петра II Петровића Његоша, Вука Стефановића Караџића, Људевита Штура... Његовом прераном смрћу, у 57 години, остала је велика празнина код Срба у том делу Мађарске (Радован Вујошевић, Ивановић, Павле Сентивански, Српски биографски речник, књ.4 (И-Ка), Нови Сад 2009, 64-65).

${ }_{12}$ Фердинанд Мајерхофер од Гринбала је рођен у Бечу 1798, а умро је у Клагенфурту 1869. године. војно образовање је стекао у поморском колегијуму у Бечу, у који је ступио 1815 . године. Непрестано се пењао у војној хијерархији да би до 1848. стекао чин пуковника. У периоду од 1844. до 1849. био је аустријски генерални конзул у Кнежевини Србији. Слао је аустријској влади сталне извештаје о приликама у Србији, Босни, Хрватској, Славонији, Црној Гори, Јужној Угарској. Када је ојачао Српски народни покрет у Угарској а тензије према Мађарима нарасле до оружаног сукоба, свесрдно је помагао Српски покрет против Мађара, штитећи при томе аустријске интересе. Пружио је подршку патријарху Рајачићу у његовом сукобу са младим и либералним Ђорђем Стратимировићем, закључивши правилно да може имати већу контролу над Покретом преко патријарха. Ускоро је постао неизбежан фактор за решавање српског питања у јужној Угарској, а после смрти војводе Стевана Шупљикца, незванично је руководио српским трупама и одбио нападе Мађара крајем децембра 1848. у Банату, за шта је 1849. унапређен у чин генерал-мајора, одликован Орденом царице Марије Терезије и проглашен за барона. После доношења Октроисаног устава 4. марта 1849. додељена му је војна и извршна власт над Војводином, као седмим војним округом у Угарској. Очувао је у свему аустријске интересе и постепено гасио сваки вид самосталности Српског народног покрета и његових органа власти. Царским патентом од 18. новембра 1849. устројено је Војводство Србија и Тамишки Банат, са седиштем у Темишвару, а његов начелник је био Мајерхофер до 1851. године, када је повучен, а 1856. и пензионисан. Упамћен је у српском народу у Монархији и каснијој нашој историографији као сива еминенција револуционарних збивања на тлу Угарске (Ненад Миленовић, Мајерхофер фон Гринбал Фердинанд, Српски биографски речник, књ. 5, Нови Сад 2011, 741).

${ }^{13}$ Исидор Николић Србоградски је умро 2. фебруара 1862. године у Сомбору. Био је врховни комесар Бачке и Торонталске жупаније и Вршачког округа, истакнути члан Матице српске. Никада у свом раду није заборавио да је Србин, од српскога рода, радио је колико год су му могућности дозвољавале за
} 
мађарским молбама и жељама. Мајерхофер се обратио мађарској депутацији и силном свету српском, буњевачком и мађарском који се био сакупио овим речима: „Ово је Војводина вијерна земља, ко није задовољан царским уредбама, може ићи напоље из Војводине. Широк а притом и срећан пут му желим...“14 Овакав тврдокоран став Мајерхофера је многе изненадио а њему се у негативном ставу према мађарској делегацији и мађарском народу у Војводству уопште, придружио и поджупан Исидор Николић са следећим речима: „Истина да сам већ заборавијо мађарски али ништа не чини да добоје мало од ползе него јављам оним допистељима који чрез новина народ побуњују да се између и под најстожијом ст[р]ажом да се имају у Темишвар послати““. ${ }^{15}$

Други део писма Ивановић је посветио приватним стварима из којих можемо сазнати да је грађански слој Срба у Монархији, ђаци, студенти, занатлије, трговци, волео одласке у природу и бање, којих је било небројено много у Угарској и били су на добром гласу, не због лечења него због забаве и статуса.

Последња страница писма, коју доносимо уз овај рад, као прилог у факсимилу, занимљива је стога што пише у поздраву својих колега њихова презимена ћирилично а имена латинично. Нисмо у могућности да утврдимо из ког разлога, можемо само да претпоставимо да или је у питању нека студентска игра, или пак можда заваравање цензуре, које је у Војводству сигурно било.

Ово писмо је занимљиво за историју и историографију Срба у Хабзбуршкој монархији XIX века из више разлога. У могућности смо да проникнемо у ставове најмеродавнијих људи у Војводству (Фердинанда Мајерхофера и Исидора Николића), као оних који су ипак тумачили Војводство као какву-такву српску творевину - посебну Круновину у оквиру Угарске. Такође се кроз њихов говор одражава став царских власти и негативан однос према Мађарима, са мислима да их треба казнити за покушај револуционарног свргавања Хабзбурга. Други део писма нам, опет, открива хтења и жеље будућег српског грађанског слоја, који никако није заостајао за немачким, водећим у то време у Монархији.

Писмо се налази у Архиву Војводине, у збирци доктора Јована Милекића, оснивача Бачког музеја у Суботици. Галерија Матице српске у Новом Саду и Градски музеј у Суботици откупили су уметничке слике и део архиве, а наследници др Јована Милекића су после његове смрти 1978. године поклонили преостали део архиве Рукописном одељењу Матице српске и Архиву Војводине у Новом Саду. Део архивалија поклоњен Архиву Војводине садржи документарни материјал који је др Јован Милекић прикупљао за књигу о знаменитим Бачванима, коју је намеравао да

Српство. Још је на Народно-црквеном сабору 1842. године имао истакнут говор о српској слози. Био је истакнути писац и песник. Памти се његова трагедија Цар Лазар, која је штампана 1835. и много пута читана, и препричавана у српском народу. Године 1841. написао је Спомене народа србскога, као изводе византијских историчара о Србима, да би 1849 , непосредно по завршетку револуционарних дешавања, написао књигу Војводство Срба аустријских. Осим тога је писао оде и неке мање песме, које су штампане у Старим србским летописима, Народном листу, Седмици. Пред смрт је имао идеју о покретању једног политичког листа назива Душан. Како у некрологу за Николића дословце стоји, „у свакој прилици био Србин сав и свугде“ (Летопис Матице српске, бр. 107, Будим 1863, 165-166).

${ }^{14}$ Архив Војводине, фонд 444, бр. а. ј. 190.

${ }^{15}$ Исто. 
напише. Од те грађе је у Архиву Војводине формирана Збирка др Јована Милекића у временском периоду од 1841. до 1963. године.

Писмо у целости, са нашим интервенцијама у угластим заградама и објашњењима, гласи :

Баја $18^{[0] \Gamma}$ марта

Љубезни Пришо!

Дошавши из ваше лијепе вароши Пеште у моју мању и простију али пријатнију, нисам хтео одма[х] описати игранку, која се исти дан држала, него љубопитљив знати одговор на молбу бивши[х] поглавара мађарски[х] коју су вручили били баш овде находећему Г[осподину] Мајерхоферу и Исидору Николићу да цео мађарски народ најмањи није задовољан са новонаименоватим старешинством, гдје су само неколице од Немаца, Мађара ниједног а прочи сами Срби и међу њима такови који су једва 24 љето пригазили - после зашто, и по којим правилу све да се Србски и немецки води, у таквој вароши где до 10 хиљада Мађара има. Тог мађарског Полсланичества приступ ко Мајерхоферу за тили часак распростресе међу Србским и буњевачким Народом /Нација/ и они у највећој јарости гомилама поиталу су пред стан Мајер[хофе]ра мислећи да ће им он мађарску молбу испунити и сва њихова зактевања тврдо испунити. Али после неколико тренутака изиђу депутација и за њима Мајерхофер и ово стадо бесједити. Ово је Војводина вијерна земља, ко није задовољан царским уредбама, може ићи напоље из Војводине. Широк а притом и срећан пут му желим и ко се тужит оће, нек се обрати на варошко племенито старешинство и оно ће по могућству сила своји ..... дати својевољно задобивеним ранама. Затим изиђо Николић и поче бесједити: Истина да сам већ заборавијо мађарски али ништа не чини да добоје мало од ползе него јављам оним допистељима који чрез новина народ побуњују да се између и под најстожијом ст[р]ажом да се имају у Темишвар послати. Затим измеђ највеће радости са Пратњом Банделиривије отиду у Сомбор.

Што се Бања тиче [оти]ћи ћу ве[ћ] при долазку мом јавит[и] се. Пишите за Лутрију какове су Намере изишле на обе лутрије ${ }^{16}$, јел ми писмо како стигло из Беча ........пошаљи јестел[и] већ разпуштени. Како живите, јесте ли сви здрави, имате ли новог шта. Како прочитам по тачности твојој, молим те одма[х], али одма[х] одпиши.

Будиме здрави

Остајем ваш брижни, Паво Ивановић

Све поздрављам, ево по класификацији ${ }^{17}$

Eminentes

Илић Stefan

Крестић nonscionones

Михајловић Teofiel

Кнезsевић Wilhelm

Cl[assa] I ${ }^{\mathrm{ma}}$

Дavisich Maxim

\footnotetext{
16 Лутрија је реч холандског порекла и означава игру на срећу. У контексту ове реченице највероватније да је реч о поштанском фаху (ормарићу) који би се закупљивао на одређеним локацијама по граду. То је време када се путовало кочијама, а железница још није стигла у Хабзбуршку монархију.

${ }^{17}$ Поздравља их по разредима (класама), где су eminentes најстарија (завршна) класа.
} 
Volianih Adam

Bakics Thomas

Cl[assa] Secundae

Сима Повић

Sility Victor

Cl[assa] Tertiae

Senex hausmajster

Fitos Narics

Јанкоvић Brokecs optessmann

Нема дана да не угријем главу.

Пришо ако си новце добијо, дођи нећеш се покајати.

На полеђини писма налази се адреса :

An Herrn herrn Vasoje Arnovljevič abzugeben

Tekelianum Instituth

Grune baumgasse en $6^{18}$

Baia

Pesth

\footnotetext{
${ }^{18}$ Сава Текелија је 1837. за 50.000 форинти купио велику, у том тренутку, оронулу кућу близу српске цркве у Пешти, будући Текелијанум. Кућа се налазила у улици која се првобитно звала Улица великог крста, а потом Улица зеленог дрвета (Божидар Ковачек, Текелијанумске историје XIX века, Нови Сад 1997, 11).
} 


\section{Извори и литература:}

Извори:

Архив Војводине, Збирка др Јована Милекића, фонд 444, бр. а. ј. 190.

Бујас, Милица, Арновљевић, Василије, Српски биографски речник, књ. 1 (А-Б), Нови Сад 2004.

Вујошевић, Радован, Ивановић, Павле Сентивански, Српски биографски речник, књ. 4 (И-Ка), Нови Сад 2009.

Летопис Матиие српске, бр. 107, Будим 1863.

Миленовић Ненад, Мајерхофер, фон Гринбал Фердинанд, Српски биографски речник, књ. 5, Нови Сад 2011.

\section{Литература:}

Гавриловић, Славко, О борби Срба у Хабзбурикој монархији за политичко-територијалну аутономију 1690-1850, Зборник Матице српске за историју, св. 43, Нови Сад 1991.

Гавриловић, Славко, Политичка борба за Српску Војводину у Аустријској иаревини 1848-1849, Зборник радова Српски покрет у Револучији 1848-1849, Нови Сад 2000,

Давидов, Динко, Споменици будимске епархије, Нови Сад 1990.

Ивановић, Павле, Нешто из прошлости вароши Баје, Летопис Матице српске, бр. 104, Пешта 1862.

Игњатовић, Јаков, Рапсодије из прошлог српског живота, Нови Сад 1953.

Ковачек, Божидар, Текелијанумске историје ХІХ века, Нови Сад 1997.

Косовац, Мато, Српска православна митрополија карловачка, Загреб 2012 (репринт).

Кркљуш, Љубомирка, Правна историја српског народа, Нови Сад 2002.

Микавица, Дејан, Српска Војводина у Хабзбуршкој монархији 1690-1920, Нови Сад 2005.

Микавица, Дејан - Гавриловић, Владан - Васин, Горан, Знаменита документа за историју сриског народа 1538-1918, Нови Сад 2007.

Шпира, Ђерђ, На прагу братоубилачког рата, Зборник радова Срби и Мађари у Револуцији 1848-1849. године, Београд 1983. 


\title{
AN 1850 LETTER FROM BAJA
}

\author{
Summary
}

In 1850 Baja was one of the centres of the Duchy of Serbia and Timisoara Banat. At the time, Serbian people still presented a vast majority there. In a letter which is the subject of this paper, a Serbian student of medicine from Baja, Pavle Ivanović, as one of the most important news mentions a riot started by Hungarian inhabitants of Baja and its vicinity, who came to town in order to complain before the governor of the Duchy, general Ferdinand Mayerhofer, who found himself there while visiting the Kingdom's towns in March 1850. In Baja he met with the vice-prefect Isidor Nikolić, and they both took a rather negative attitude towards Hungarian petitions and requests saying that they were in Baja, which was a part of the Duchy of Serbia and Timisoara Banat, and therefore they primarily advocated Serbian interests.

Keywords: Baja, Duchy of Serbia and Timisoara Banat, Pavle Ivanović, Vasa Arnovljević, Ferdinand Mayerhoher, Isidor Nikolić. 